Jurnal Indonesia Sosial Teknologi: p-ISSN: 2723 - 6609

e-ISSN : 2745-5254

Vol. 2, No. 10 Oktober 2021

\title{
FAULT SEAL ANALYSIS MENGGUNAKAN METODE SHALE GOUGE RATIO PADA RESERVOIR BATUGAMPING FORMASI KAIS LAPANGAN “AR".
}

\author{
Arief Rahman ${ }^{1}$, Warto Utomo ${ }^{2}$, Bangbang Panca Kusuma ${ }^{3}$, dan Muhammad \\ Thariq Almuqtadir ${ }^{4}$ \\ Akamigas Balongan Indramayu ${ }^{1,2,3}$ Pertamina EP Regional $\mathrm{IV}^{4}$. \\ Email: arief11rahman@gmail.com ${ }^{1}$, bunk.w.utomo@gmail.com², \\ bangbangpanca5@gmail.com ${ }^{3}$,muhammad.almuqtadir@pertamina.com ${ }^{4}$
}

\begin{abstract}
Abstrak
Fault Seal Analysis (FSA) adalah analisis untuk menentukan patahan/sesar bersifat sealing (tersekat) atau leaking (bocor). Salah satu metode untuk menentukan FSA adalah Shale Gouge Ratio (SGR) yang pertama kali dikemukaan oleh Yielding (1997). Tujuan penelitian ini menentukan sealing atau leaking patahan pada batugamping Formasi Kais lapangan "AR" Cekungan Bintuni, Papua Barat, dan analisis pengaruh ketebalan lapisan $(\Delta \mathrm{z})$ dan volume shale (Vsh) dalam rumus SGR. Data penelitian yang digunakan yaitu satu sumur minyak (sumur AR-3), penampang lapisan formasi, dan throw dari 3 (tiga) patahan (F1, F2, F3) di sekitar sumur tersebut. Metode penelitian adalah SGR untuk menentukan sealing atau leaking, sedangkan analisis pengaruh ketebalan lapisan $(\Delta \mathrm{z})$ dan volume shale (Vsh) dalam rumus SGR dilihat berdasarkan $R$ square dari grafik antara $\Delta \mathrm{z}$ dengan SGR, dan grafik antara Vsh dengan SGR, untuk tiga patahan tersebut. Hasil penelitiannya yaitu; dari tujuh lapisan di dalam satu tubuh formasi Kais, didapatkan berbagai macam sifat leaking, sealing / leaking, dan sealing, di tiga patahan ( $\mathrm{F} 1$, F2, F3). Namun, SGR Formasi Kais dengan tebal $270 \mathrm{ft}$ dan Vsh 21\%, maka nilai SGR selalu lebih dari $100 \%$ yang berarti sealing. Hasil nilai $R$ square grafik $\Delta \mathrm{z}$ terhadap SGR $=0,743$ jauh lebih tinggi dibanding Vsh terhadap $\mathrm{SGR}=0,036$. Kesimpulannya; nilai total ketebalan shale ( $\left.\Delta \mathrm{z}^{*} \mathrm{Vsh}\right)$ harus lebih kecil sama dengan dengan nilai throw fault-nya, atau dapat ditulis $\Delta \mathrm{z}^{*}$ Vsh $\leq$ Throw Fault, jika tidak, maka nilai SGR akan selalu melebihi $100 \%$. Rumus SGR jauh lebih dipengaruhi oleh ketebalan lapisan $(\Delta \mathrm{z})$, dibanding dengan Volume Shale (Vsh).
\end{abstract}

Kata kunci: Fault Seal Analysis; SGR; Batugamping; dan Formasi Kais.

\section{Abstract}

Fault Seal Analysis (FSA) is an analysis to determine whether the fault is sealing or leaking. One of the methods to determine FSA is the Shale Gouge Ratio (SGR) which was first proposed by Yielding (1997). The purpose of this study is to determine the sealing or leaking of faults in the limestone of the Kais Formation "AR" field in the Bintuni Basin, West Papua, and the effect of layer thickness ( $\Delta z)$ and shale volume (Vsh) in the SGR formula. The research data used are one oil well (AR-3 well), a cross section of the formation layer, and throws from 3 (three) faults $(F 1, F 2, F 3)$ around the well. The research method is SGR to determine sealing or leaking, while the analysis of the effect of layer thickness $(\Delta z)$ and shale 
Fault Seal Analysis Menggunakan Metode Shale Gouge Ratio Pada Reservoir Batugamping Formasi Kais Lapangan "AR”

volume (Vsh) in the SGR formula is based on the $R$ square of the graph between $\Delta z$ and $S G R$, and the graph between Vsh and SGR, for these triple faults. The research results are; from seven layers in one body of the Kais formation, various leaking, sealing / leaking, and sealing properties were obtained, in three faults (F1, F2, F3). However, the SGR of the Kais Formation is $270 \mathrm{ft}$ thick and Vsh 21\%, so the SGR value is always more than 100\% which means sealing. The result of the $R$ square value of the z graph to $S G R=0.743$ is much higher than Vsh to $S G R=0.036$. In conclusion; the total value of the shale thickness $\left(\Delta z^{*} V s h\right)$ must be less than the value of the throw fault, or it can be written $z^{*} V$ sh Throw Fault, otherwise the SGR value will always exceed 100\%. The SGR formula is much more affected by the layer thickness ( $\Delta z)$, compared to the Shale Volume (Vsh).

Keywords: Fault Seal Analysis, SGR, Limestone, and Kais Formation.

\section{Pendahuluan}

Lokasi Lapangan "AR" (nama alias) terletak di Kabupaten Teluk Bintuni, Provinsi Papua Barat. Lapangan ini termasuk dalam area yang sudah terbukti menghasilkan minyak dan gas bumi, yaitu cekungan Bintuni. Berdasarkan Badan Geologi (2010, dalam ( memiliki luas $\pm 30.000 \mathrm{~km}$. Lihat Gambar 1 .

\section{$\underline{\text { Geologi Regional }}$}

Cekungan Bintuni terbentuk saat Tersier Akhir yang mengalami perkembangan selama Plio-Pleistosen bersamaan dengan pengangkatan pegunungan Lipatan Lengguru (Lengguru Foldbelt) di sebelah timur dan Tinggian Kemum sebelah utara (Pigram dan Sukanta, 1981, dalam (Rasimeng, Ririn, Karyanto, Hidayat, \& Muhammad Indragiri, 2018). Lihat Gambar 2.

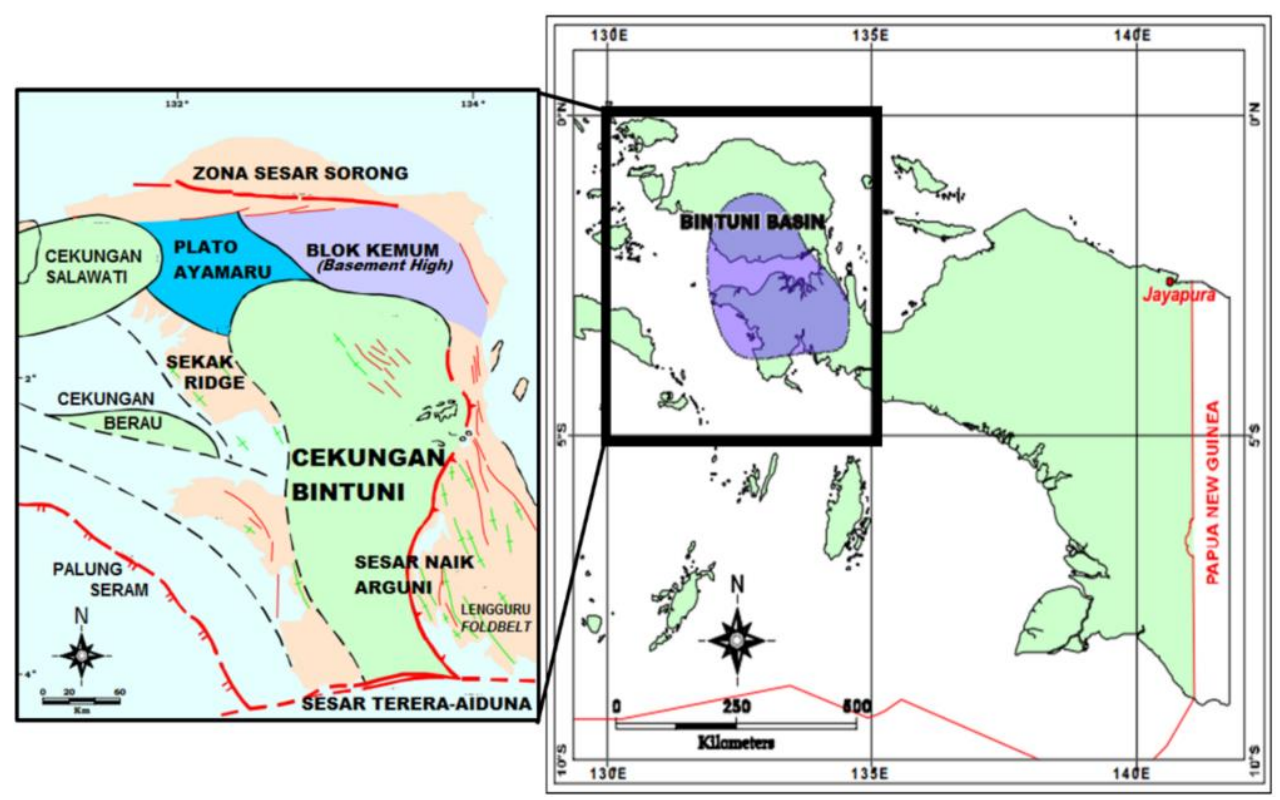

Gambar 1 
Arief Rahman, Warto Utomo, Bangbang Panca Kusuma, Muhammad Thariq Almuqtadir

Lokasi Cekungan Bintuni (Maulananingsih, Hartantyo, \& Anggraini, 2015) diperbarui dari Chevallier dan Bordenave (1986), dalam ( Patra Nusa Data, 2006).

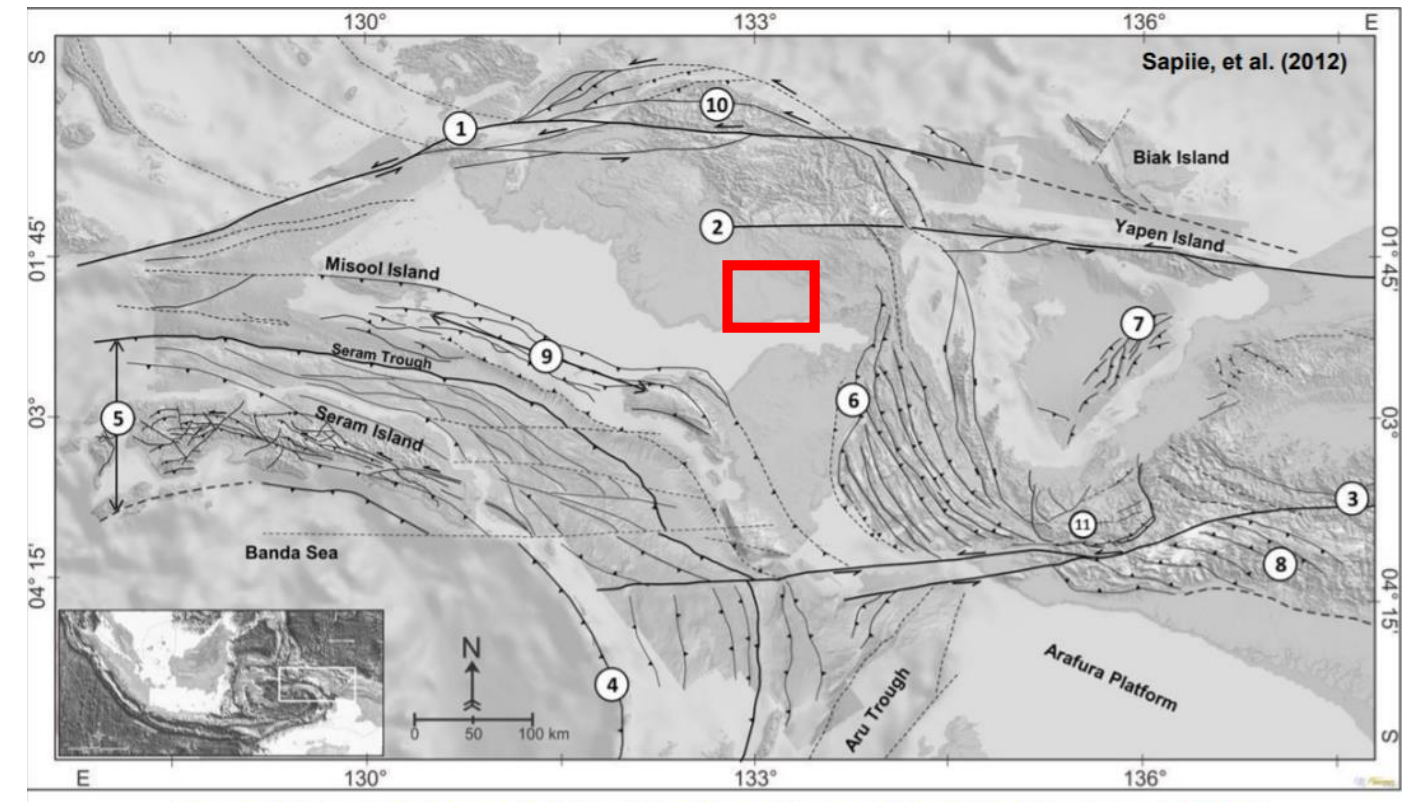

1. Sorong Fault Zone (SFZ), 2. Yapen Fault Zone (YFZ), 3. Tarera-Aiduna Fault Zone (TAFZ), 4. Banda Trench, 5. Seram Fold-Thrust-Belt (SFTB), 6. Lengguru Fold-Thrust-Belt (LFTB), 7. Cendrawasih Bay Fold-Thrust-Belt (CBFTB), 8. Central Range Fold-Thrust-Belt (CRFTB), 9. Misool-Onin-Kumawa Ridge (MOKR), 10. Kemum High, 11. Weyland Overthrust.

\section{Gambar 2}

Area penelitian (kotak merah) dikelilingi patahan naik dan patahan geser (Sapiie,

Naryanto, Adyagharini, \& Pamumpuni, 2012) .

Formasi target di penelitian ini adalah Formasi Kais yang mempunyai litologi batugamping, dengan disisipi serpih (shale). Lihat Gambar 3.

\section{Petroleum System}

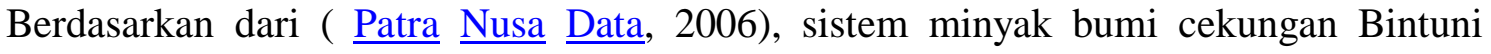
adalah sebagai berikut:

\section{A. Batuan Induk}

Batuan sumber potensial terjadi terutama di tiga zona: Formasi Permian Ainim Akhir serpih dan batubara kontinental, Formasi Jurassic Awal hingga Tengah dibatasi laut untuk serpih dan batubara kontinental, dan Batulempung berkapur laut Tersier dan batugamping Formasi Waripi dan Kelompok Batugamping Nugini.

Batuan induk (source rock) Permian Akhir terjadi di bagian paling atas dari sikuen rift dan mendasari reservoir gas-bearing Jurassic post-rift awal di sumur penemuan Teluk Bintuni. Semua diendapkan sebagai serpih karbon dan batubara di lingkungan pengendapan paludal dan danau. Kandungan karbon organik berkisar antara $87 \%$ hingga $88 \%$ yang menunjukkan bahwa banyak dari batubara ini mengandung komponen argillaceous yang signifikan. Potensi hasil pirolisis yang tinggi menunjukkan potensi menghasilkan (migas) yang sangat baik. 
Fault Seal Analysis Menggunakan Metode Shale Gouge Ratio Pada Reservoir Batugamping Formasi Kais Lapangan "AR”

Batuan induk Jurassic Awal hingga Tengah mewakili sedimen pertama yang diendapkan setelah permulaan siklus transgresif utama dan terdiri dari serpih dan batubara yang diendapkan di lingkungan laut non-laut hingga marjinal marin. Indeks hidrogen pirolisis menunjukkan variasi utama (13-313), tetapi umumnya lebih besar dari 200 yang menunjukkan kematangan kerogen terutama humic tetapi dengan komponen sapropelik terbukti minyak (oil-prone sapropelic) yang signifikan pada kematangan saat ini.

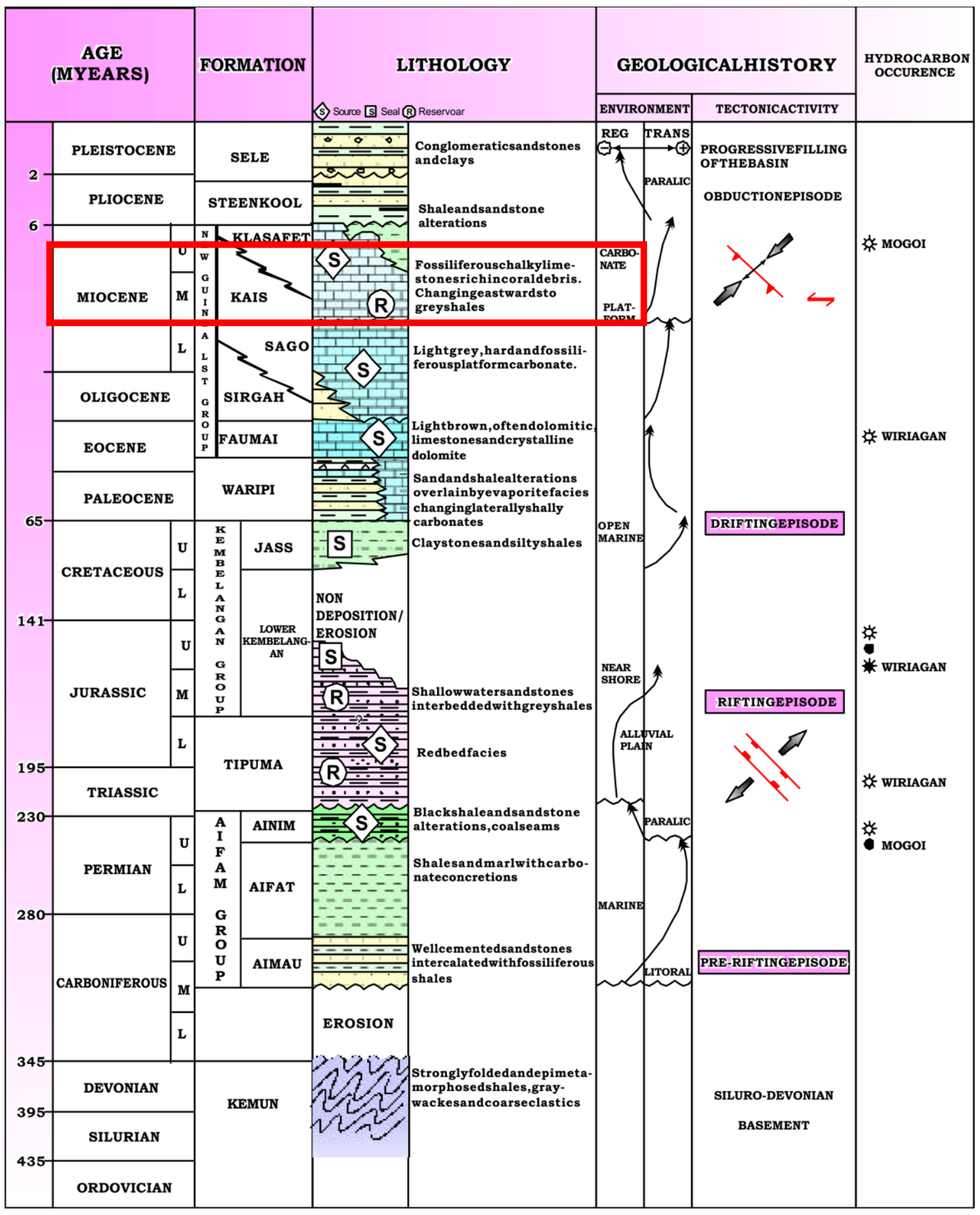

Gambar 3 
Arief Rahman, Warto Utomo, Bangbang Panca Kusuma, Muhammad Thariq Almuqtadir

Kolom Stratigtafi Regional Cekungan Bintuni DATA, (2006) dalam (Handyarso \& Mauluda, 2018). Formasi target adalah Formasi Kais (kotak merah). diperbarui dari Chevallier dan Bordenave 1986, dalam ( Patra Nusa Data, 2006)

\section{B. Reservoir}

Reservoir gas-bearing utama terjadi di batupasir fluvio-deltaic masif Jurassic Tengah hingga Akhir yang ditugaskan ke Grup Kembelangan Bawah. Pola log sumur batupasir umumnya memiliki bentuk runcing (sharp), erosional pada bagian bawah, bentuk "bell" atau silinder. Batupasir tersebut diinterpretasikan terutama telah diendapkan di bawah kondisi yang didominasi fluvial pada "point bar" atau distribusi sungai.

Formasi Kais juga merupakan reservoir utama di Cekungan Bintuni. Formasi ini terbagi menjadi dua anggota: batugamping Kais berpori dan anggota Sekau yang terdiri dari "batugamping nodular karang".

Minyak terbatas diproduksi dari anggota Sekau tetapi batugamping Kais biasanya mengandung air tawar, dan memiliki kualitas reservoir yang buruk karena kurangnya permeabilitas. Di bagian Cekungan Bintuni yang lebih tua, Formasi Tipuma menyediakan potensi reservoir pasir yang sangat baik. Reservoir penting sekunder termasuk Formasi Ainim.

\section{Seals Rock (Batuan Penutup)}

Batuan penutup (seal rock) regional ada di Cekungan Bintuni, Batulempung Kembelangan Atas dan Bawah Jurassic Akhir hingga Eosen dan serpih, yang menutup (menjadi penghalang) gas yang terperangkap di batupasir Kembelangan Atas dan Bawah. Batulempung Miosen Akhir dan Batulempung Steenkool Terbaru, yang menutup akumulasi minyak Batugamping Nugini.

Formasi Jass di Cekungan Bintuni sebagian besar terdiri dari serpih laut dan serpih karbonat dengan banyak lapisan batupasir tipis. Serpih laut kapur ini akan membentuk batuan penutup efektif di atas bagian Jurassic atau yang lebih tua.

D. Migrasi

Migrasi diyakini telah terjadi di sepanjang sisi barat laut Cekungan Bintuni yang landai di sepanjang sumbu antiklinal regional dengan jarak lebih dari lima puluh kilometer.

Migrasi jarak jauh dibantu oleh interpretasi masif, berkelanjutan alami dari postrift. Reservoir batupasir delta Jurassic, yang memiliki akses luas ke batuan induk Jurassic interbedded post-rift dan mendasari urutan rift yang batuan induk Permian.

Migrasi gas baru-baru ini dari dalaman Cekungan Bintuni mungkin telah menggantikan minyak yang bermigrasi dari batuan induk yang lebih dangkal ke dalam perangkap di sisi cekungan, termasuk perangkap Roabiba yang berisi kondensat fraksional yang berasal dari minyak.

\section{E. Perangkap Migas (Oil and Gas Trap)}

Konfigurasi tektonik/cekungan yang mengontrol migrasi dan perangkap hidrokarbon dari batuan induk Pra-Tersier ke reservoir Jurassic. Penemuan gas 
Fault Seal Analysis Menggunakan Metode Shale Gouge Ratio Pada Reservoir Batugamping Formasi Kais Lapangan "AR”

Roabiba-1 dibor di atas papan, struktur dengan relief rendah dip-closed di tingkat Jurassic teratas yang terletak di sumbu antiklinal regional terjun tenggara. Penutupan di ujung utara struktur Owaferi bergantung pada patahan. Penemuan gas Wos-1 dibor pada struktur "bunga" (flower structure) yang terbentuk di sepanjang salah satu patahan kunci E-W utama. Lihat Gambar 4.

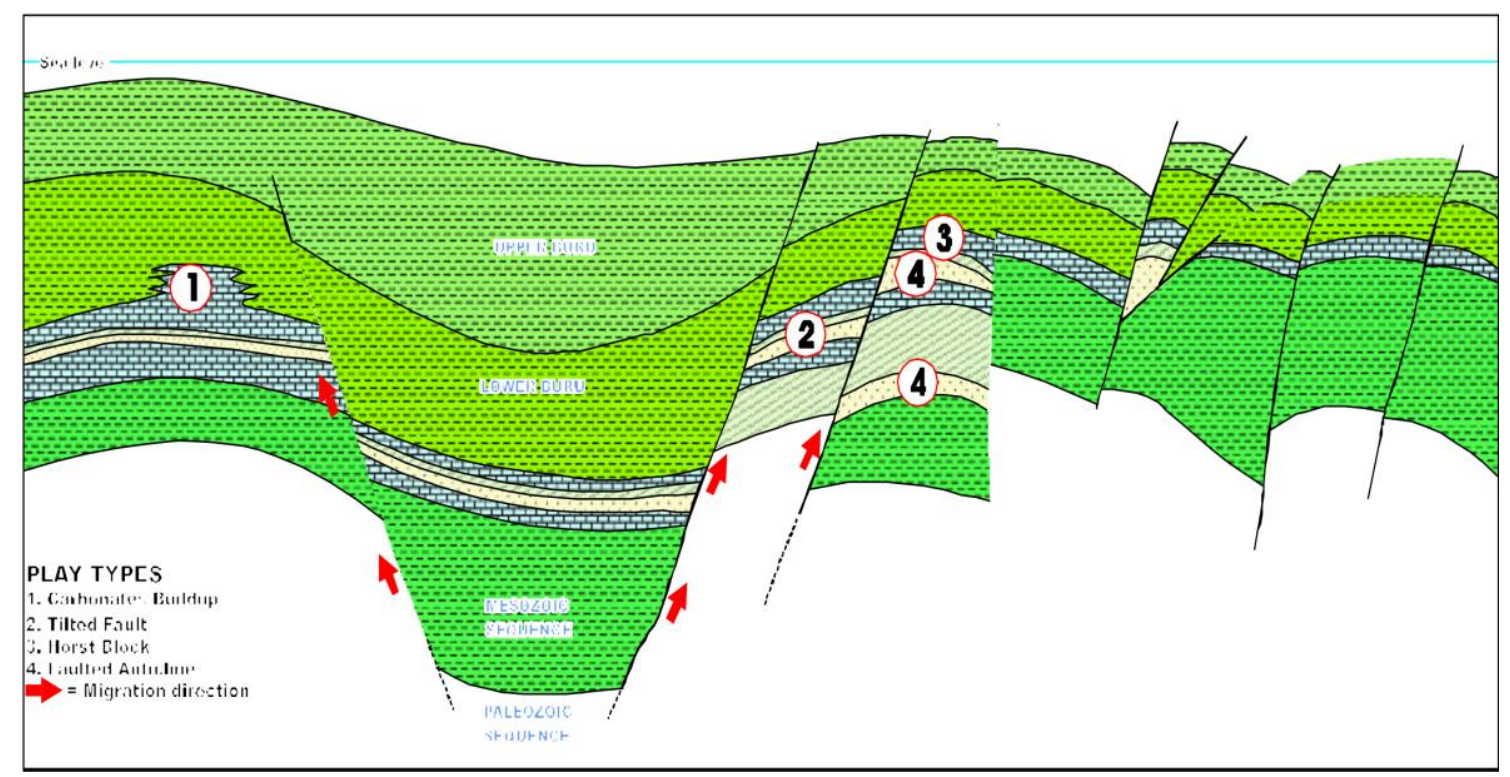

Gambar 4

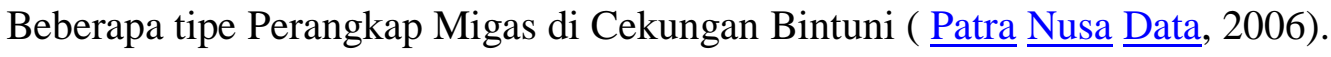

\section{Formasi Kais Lapangan "AR"}

Lapangan "AR" ditemukan pada tahun 1981. Minyak terperangkap di batugamping Formasi Kais yang berumur Miosen Atas yang berkembang pada fasies reefal, lagoonal dan shoreface. Perangkap di Lapangan "AR" terbentuk oleh kombinasi proses struktural, stratigrafi dan diagenetik. Terumbu tersebut kemungkinan berkembang pada ketinggian lokal yang dihasilkan oleh lipatan kala Oligosen Akhir. Kompresi berarah timur-barat berikutnya di Pliosen menciptakan perangkap struktural. Selain itu, perangkap minyak telah difasilitasi oleh adanya zona rapat berpori rendah, yang melindungi akumulasi minyak dari pembilasan air tawar (meteoric water). Zona ketat, mengalami sejarah diagenesa yang berbeda dibandingkan dengan reservoir berpori di atasnya. Deskripsi dan zonasi reservoir dihasilkan dari pengenalan fasies pengendapan primer, sejarah diagenesa dan analisis petrofisika intervalnya. Kontak fluida minyak-air atau Oil Water Contact (OWC) lapangan dibuat dengan membandingkan data analisis log, tampilan hidrokarbon di inti dan analisis repeat formation test RFT. Di wilayah Kontrak Kerja Kepala Burung Selatan (KBS), setelah 18 sumur eksplorasi dibor hingga saat ini untuk menguji tujuan Formasi Kais, minyak hanya ditemukan di Lapangan "AR". Akumulasi tidak dikendalikan hanya oleh fasies pengendapan atau diagenesa, tetapi dijelaskan oleh serangkaian keadaan yang unik yang memungkinkan minyak bermigrasi dari batuan induk Pra-Tersier yang dalam, matang, 
Arief Rahman, Warto Utomo, Bangbang Panca Kusuma, Muhammad Thariq Almuqtadir

ke dalam reservoir dalam Formasi Kais. Sumber minyak yang paling mungkin adalah Formasi Kembelangan yang berumur Jura, meskipun lebih dari satu sumber telah disarankan oleh hasil studi inklusi fluida dan analisis geokimia. Migrasi mungkin terjadi di sepanjang patahan kunci Pliosen, di daerah dimana Formasi Jass yang berumur Kapur relatif tipis. Formasi Jass dianggap sebagai regional seal untuk hidrokarbon yang berpotensi terperangkap di reservoir Jura atau Trias di tempat lain di area KBS. Eksplorasi masa depan di area tersebut akan diarahkan ke Pre-Tertiary Play yang relatif belum teruji (Dolan, 1988).

\section{Fault Seal Analysis}

Fault Seal Analysis (FSA) atau Analisis Sekatan Sesar adalah analisis untuk menentukan patahan/sesar bersifat sealing (menutup/ menyekat/ menghalangi/ menahan) atau leaking (menyalurkan/ mengalirkan/ meneruskan/ melewatkan). Berbagai metode untuk menentukan analisis sekatan sesar, satu diantaranya adalah Shale Gouge Ratio (SGR) yaitu penentuan sealing/leaking melibatkan kandungan polisilikat (Vsh atau Vclay) suatu interval lapisan di suatu patahan. Lihat Gambar 5.

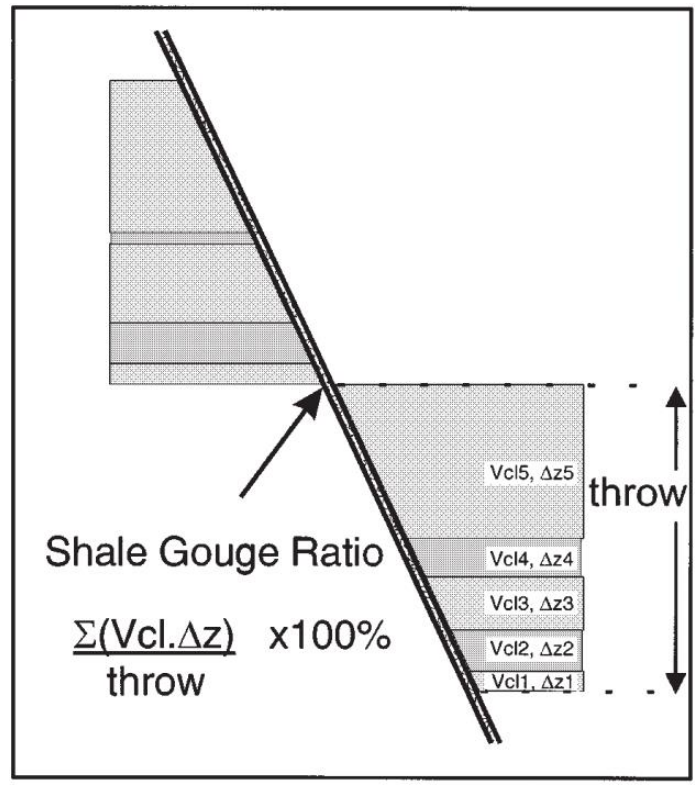

Gambar 5

Skema SGR untuk analisis sekatan sesar (Yielding, Freeman, \& Needham, 1997)

Rumus SGR atau Shale Gouge Ratio pertama kali dikemukaan oleh (Yielding et al., 1997), yaitu:

$$
\mathrm{SGR}=\sum(\operatorname{Vsh} \times \Delta \mathrm{z} / \text { throw }) \times 100 \%
$$

Dimana:

Vsh = Volume Shale (serpih)

GR $=\log$ Gamma Ray

$\Delta \mathrm{z} \quad=$ interval lapisan 
Fault Seal Analysis Menggunakan Metode Shale Gouge Ratio Pada Reservoir Batugamping Formasi Kais Lapangan "AR"

Throw $=$ komponen vertikal pemisahan lapisan pada suatu patahan

Variabel rumus dalam SGR diantaranya adalah Volume shale (Vsh) atau jumlah kandungan shale/clay dalam suatu batuan (Petroleum ID, 2020). Berbagai cara untuk menentukan Vsh. Salah satu caranya adalah menggunakan log GR (Gamma Ray) dari sumur pengeboran. Rumus Vsh atau Volume shale :

$$
\mathrm{Vsh}=\frac{\mathrm{GR} \log -\mathrm{GR} \min }{\mathrm{GR} \max -\mathrm{GR} \min }
$$

Dimana:

GR log = log Gamma Ray (GR) pada titik kedalaman tertentu.

GR $\min =\log$ GR minimal pada formasi / zona target

GR $\max =\log$ GR maksimal pada formasi / zona target

\section{Tujuan Fault Seal Analysis (FSA)}

Tujuan dilakukan FSA untuk mengetahui apakah lapisan reservoir migas suatu lapangan dengan lapangan lain yang dibatasi oleh suatu sesar / patahan, terkoneksi atau tidak terkoneksi.

Batuan reservoir migas yang sangat banyak dijumpai adalah batupasir dan batugamping. Berikut ini nilai SGR untuk kedua litologi batuan reservoir jika berselingan dengan shale berdasarkan penelitian terdahulu.

\section{Tabel 1}

Penentuan Sealing dan Leaking perselingan antara batupasir-serpih (Yielding et al., 1997), (Ghifary Ardiansyah, Sapto Mulyanto, Haerudin, \& Purba, 2018), dan (Hartanto, Sapiie, Gunawan, \& Wibowo, 2018), berdasarkan nilai SGR.

\begin{tabular}{|l|c|c|}
\hline Perbandingan & Batupasir - serpih & Batugamping (terumbu) - serpih \\
\hline Leaking & $<20 \%$ & $\leq 16 \%$ \\
\hline Sealing & $>20 \%$ & $>35 \%$ \\
\hline
\end{tabular}

Selama ini, banyak publikasi SGR difokuskan pada penentuan sealing atau leaking antar kompartemen atau bagian lapangan migas yang dipisahkan oleh patahan (fault). Pembahasan terbaru dari tulisan ini bukan hanya penentuan sifat / klasifikasi sealing atau leaking suatu patahan, tapi pengaruh ketebalan lapisan atau interval $(\Delta \mathrm{z})$, dalam menghasilkan nilai SGR, sebelum akhirnya "menjatuhkan vonis" sifat patahan tersebut.

\section{Metode Penelitian}

Data yang tersedia di lapangan “AR”, cekungan Bintuni, Papua Barat, yaitu: log GR dari satu Sumur "AR-3", satu penampang lapisan barat-timur dari Formasi Kais 
Arief Rahman, Warto Utomo, Bangbang Panca Kusuma, Muhammad Thariq Almuqtadir

(formasi target). Lapangan ini terdiri dari tujuh (7) lapisan target sebagai reservoir minyak bumi, yaitu : Kais IA pada 1530 - $1557 \mathrm{ft}$ Kais IB pada 1557 - $1570 \mathrm{ft}$; Kais II 1570 - 1650 ft; Kais III pada 1650 - 1662 ft, Kais IVA pada 1662 - 1681 ft, Kais IVB pada 1682 - $1742 \mathrm{ft}$ dan Kais IVC pada 1742 - $1800 \mathrm{ft}$. Lihat Gambar 6.

Di lapangan ini terdapat 3 (tiga) patahan (diberi nama F1, F2, dan F3) yang masih dalam area kontur OWC Formasi Kais, dengan masing-masing nilai throw fault sudah diketahui sebelumnya yaitu $\mathrm{F} 1=45 \mathrm{ft}, \mathrm{F} 2=30 \mathrm{ft}$, dan F3 = $35 \mathrm{ft}$. tiga patahan terebut bersifat naik-geser sesuai geologi regional cekungan Bintuni. Lihat Gambar 7.

Pengolahan data awal dimulai dari menentukan ketebalan lapisan $(\Delta \mathrm{z})$, dan nilai Vsh dari tiap lapisan dan interval keseluruhan Formasi Kais, dari log GR. Kemudian ditentukan nilai SGR nya untuk diklasifiksian atau bersifat leaking (0-16\%), sealing (35-100\%), dan leaking / sealing atau tidak dapat didefinisikan (17-34\%), berdasarkan Tabel 1, pada litologi batugamping (terumbu) - serpih atau shale, sesuai dengan litologi pada Formasi Kais, yaitu batugamping dengan sisipan shale. Selanjutnya, dilakukan beberapa analisis pengaruh ketebalan lapisan terhadap nilai SGR.

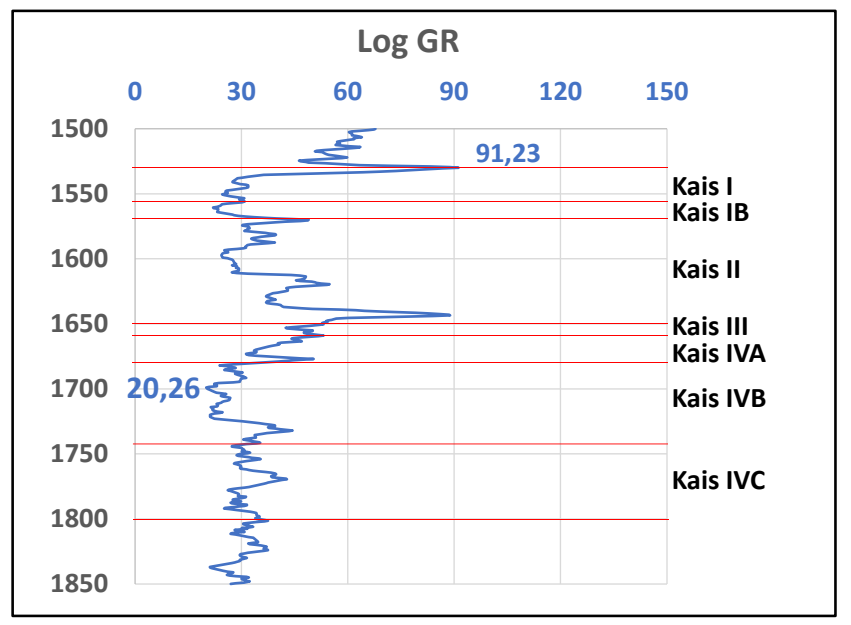

Gambar 6

Lapisan Target Kais I s.d IVC, dan Penentuan nilai GR min (20,26), dan GR maks $(91,23)$.

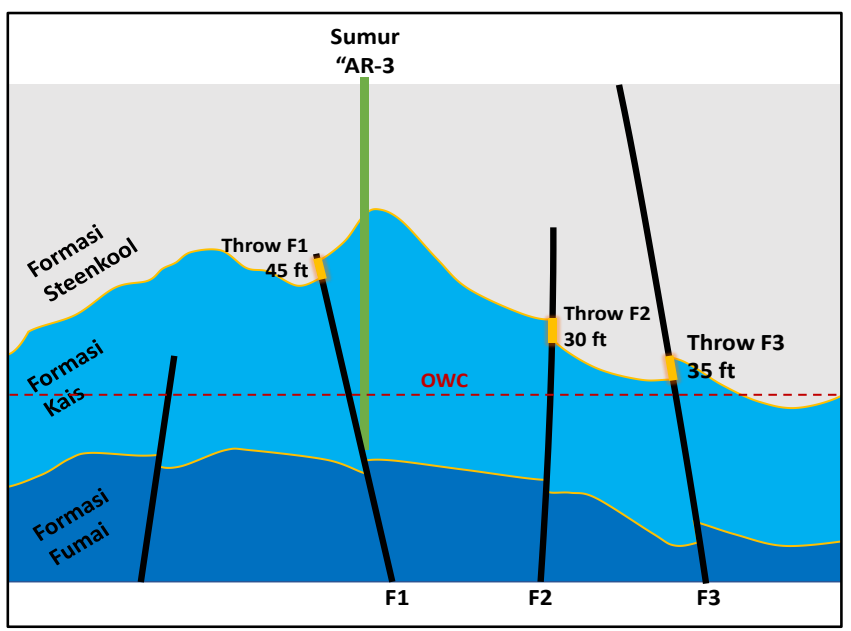

Gambar 7 
Fault Seal Analysis Menggunakan Metode Shale Gouge Ratio Pada Reservoir Batugamping Formasi Kais Lapangan "AR"

Penampang lapisan barat-timur dari Formasi Kais. Patahan naik-geser F1, F2, dan F3.

\section{Hasil dan Pembahasan}

Perbandingan SGR Tiap Lapisan dengan SGR Formasi

Nilai GR min dan GR maks yang sudah ditentukan kemudian digunakan untuk menghitung Volume Shale (Vsh) tiap lapisan (Kais I s.d kais IVC), dan menghitung Vsh keseluruhan (Formasi Kais). Nilai Vsh yang didapat dari tiap lapisan tersebut kemudian digunakan untuk menghitung masing-masing nilai SGR, dengan memasukkan masingmasing ketebalan nilai $\Delta \mathrm{z}$, dan throw tiap patahan (F1, F2, dan F3). Hasil perhitungan SGR dan klasifikasi sifat patahannya dapat dilihat pada Tabel 2 dan Tabel 3.

Tabel 2

Hasil Perhitungan SGR tiga (3) patahan (fault) tiap lapisan.

\begin{tabular}{cccccccccccccc}
\hline No. Lapisan & Vsh & $\boldsymbol{\Delta} \mathbf{z}$ & Vsh* $\mathbf{\Delta z}$ & F1 & F2 & F3 & $\begin{array}{c}\text { SGR } \\
\text { F1 }\end{array}$ & Sifat Patahan & $\begin{array}{c}\text { SGR } \\
\text { F2 }\end{array}$ & Sifat Patahan & $\begin{array}{c}\text { SGR } \\
\text { F3 }\end{array}$ & Sifat Patahan \\
\hline 1 & Kais I A & $24 \%$ & 27 & 6,53 & 45 & 30 & 35 & $15 \%$ & Leaking & $22 \%$ & Sealing/Leaking & $19 \%$ & Sealing/Leaking \\
\hline 2 & Kais I B & $11 \%$ & 13 & 1,40 & 45 & 30 & 35 & $3 \%$ & Leaking & $5 \%$ & Leaking & $4 \%$ & Leaking \\
\hline 3 & Kais II & $28 \%$ & 80 & 22,75 & 45 & 30 & 35 & $51 \%$ & Sealing & $76 \%$ & Sealing & $65 \%$ & Sealing \\
\hline 4 & Kais III & $39 \%$ & 12 & 4,69 & 45 & 30 & 35 & $10 \%$ & Leaking & $16 \%$ & Leaking & $13 \%$ & Leaking \\
\hline 5 & Kais IV A & $26 \%$ & 19 & 4,88 & 45 & 30 & 35 & $11 \%$ & Leaking & $16 \%$ & Sealing/Leaking & $14 \%$ & Leaking \\
\hline 6 & Kais IV B & $11 \%$ & 61 & 6,75 & 45 & 30 & 35 & $15 \%$ & Sealing/Leaking & $23 \%$ & Sealing/Leaking & $19 \%$ & Sealing/Leaking \\
\hline 7 & Kais IV C & $16 \%$ & 58 & 9,54 & 45 & 30 & 35 & $21 \%$ & Sealing/Leaking & $32 \%$ & Sealing & $27 \%$ & Sealing/Leaking \\
\hline
\end{tabular}

Tabel 3

Hasil Perhitungan SGR tiga (3) patahan (fault) Formasi Kais.

\begin{tabular}{ccccccccccccc}
\hline Lapisan & Vsh & $\boldsymbol{\Delta z}$ & Vsh* $\mathbf{\Delta z}$ & F1 & F2 & F3 & SGR F1 Sifat Patahan & SGR F2 & Sifat Patahan & SGR F3 & Sifat Patahan \\
\hline Formasi Kais & $21 \%$ & 270 & 56,55 & 45 & 30 & 35 & $126 \%$ & Sealing & $189 \%$ & Sealing & $162 \%$ & Sealing \\
\hline
\end{tabular}

Di Tabel 2, berbagai variasi nilai Vsh dan $\Delta \mathrm{z}$ dari tujuh lapisan di dalam satu tubuh formasi Kais, didapatkan berbagai macam sifat/klasifikasi leaking, sealing I leaking, dan sealing, di tiap patahan (F1, F2, F3). Namun, jika SGR dihitung keseluruhan Formasi Kais yang mempunyai tebal $270 \mathrm{ft}$ dan Vsh 21\%, maka nilai SGR yang didapatkan di atas atau lebih dari $100 \%$ di 3 (tiga) patahan tersebut atau sealing semuanya, seperti ditunjukkan pada Tabel 3.

Di kedua tabel tersebut, didapat kesimpulan bahwa nilai total ketebalan shale $\left(\Delta \mathrm{z}^{*} \mathrm{Vsh}\right)$ atau perkalian antara ketebalan lapisan $(\Delta \mathrm{z})$, dibanding dengan Volume Shale (Vsh) adalah harus lebih kecil sama dengan dengan nilai throw fault-nya, atau dapat ditulis $\Delta \mathrm{z}^{*}$ Vsh $\leq$ Throw Fault. Jika tidak diterapkan hal tersebut, maka nilai SGR akan selalu diatas $100 \%$.

$\underline{\text { Signifikansi antara } \Delta \mathrm{z} \text { dan Vsh terhadap nilai SGR }}$

Selanjutnya dibahas mengenai seberapa besar pengaruh ketebalan lapisan $(\Delta \mathrm{z})$ dan Volume Shale (Vsh) dalam perhitungan SGR. Cara yang dilakukan adalah membuat 
Arief Rahman, Warto Utomo, Bangbang Panca Kusuma, Muhammad Thariq Almuqtadir

grafik antara Vsh dengan SGR, dan grafik $\Delta z$ dengan SGR. Input nilai diambil dari Tabel 2. Hasil grafik ditampilkan dalam Gambar 8 dan Gambar 9.

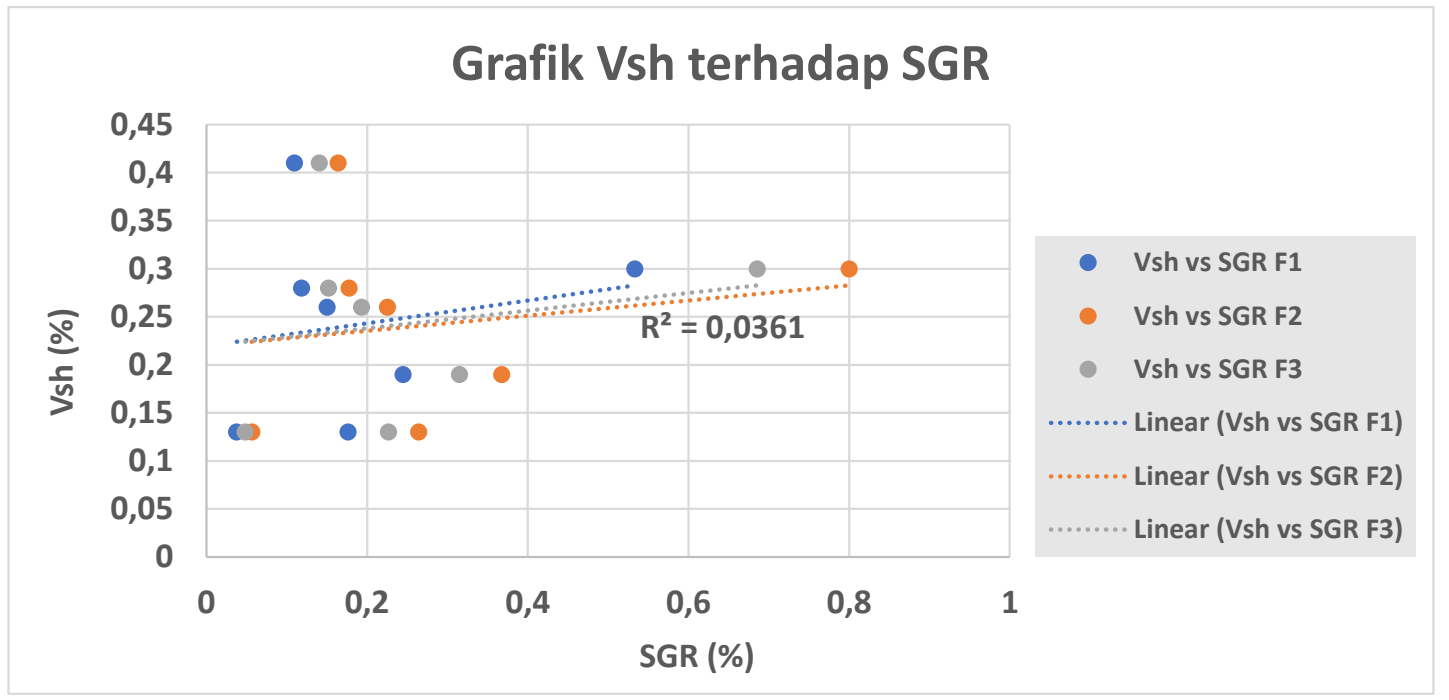

Gambar 8

Grafik Vsh terhadap SGR tiga (3) patahan (fault) tiap lapisan.

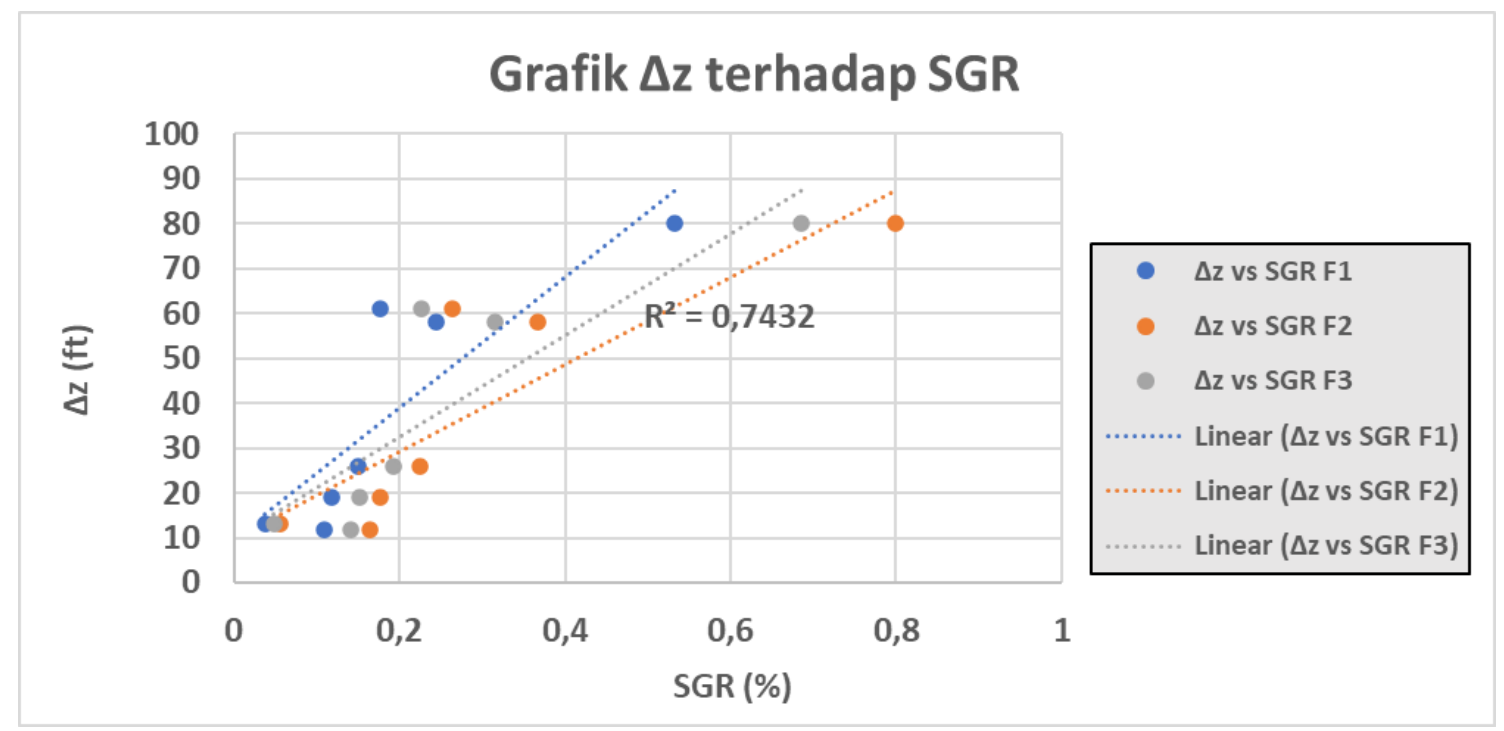

Gambar 9

Grafik $\Delta \mathrm{z}$ terhadap SGR tiga (3) patahan (fault) tiap lapisan.

Hasil dari $\mathrm{R}$ square atau koefisien determinasi $\left(\mathrm{R}^{2}\right)$ didapat dengan nilai paling tinggi yaitu 1,00. Jika nilai R Square semakin mendekati 1 (satu), maka pengaruh tersebut akan semakin kuat, dan sebaliknya (Aryani \& Gustian, 2019).

1. Sebaran nilainya lebih "scatter" (menyebar), dibanding grafik $\Delta \mathrm{z}$ terhadap SGR sebaran nilainya lebih baik dalam menunjukkan bentuk tren linear, 
Fault Seal Analysis Menggunakan Metode Shale Gouge Ratio Pada Reservoir Batugamping Formasi Kais Lapangan "AR"

2. Nilai R square dari keduanya yang sangat jauh berbeda; Vsh terhadap SGR = 0,036 berbanding $\Delta \mathrm{z}$ terhadap $\mathrm{SGR}=0,743$.

Dari dua poin diatas, didapat kesimpulan bahwa hasil perhitungan SGR jauh lebih dipengaruhi oleh ketebalan lapisan $(\Delta \mathrm{z})$, dibanding dengan Volume Shale (Vsh), hal ini dibuktikan nilai $\mathrm{R}$ square masing-masing grafik tersebut.

\section{Kesimpulan}

Berdasarkan hasil penelitian ini, dapat dituliskan kesimpulan sebagai berikut:

1. Saat menghitung SGR, pastikan bahwa nilai total ketebalan shale ( $\Delta \mathrm{z}^{*}$ Vsh) harus lebih kecil sama dengan dengan nilai throw fault-nya, atau dapat ditulis $\Delta \mathrm{z}^{*} \mathrm{Vsh} \leq$ Throw Fault. Jika tidak diterapkan hal tersebut, maka nilai SGR akan selalu diatas / melebihi $100 \%$.

2. Hasil perhitungan SGR jauh lebih dipengaruhi oleh ketebalan lapisan $(\Delta \mathrm{z})$, dibanding dengan Volume Shale (Vsh), dilihat dari bentuk grafik Vsh terhadap SGR sebaran nilainya lebih "scatter" (menyebar), dibanding grafik $\Delta \mathrm{z}$ terhadap SGR sebaran nilainya lebih baik dalam menunjukkan bentuk tren linear, hal ini dibuktikan dengan perbedaan nilai $\mathrm{R}$ square dari keduanya yang sangat jauh berbeda; Vsh terhadap SGR $=0,036$ berbanding $\Delta z$ terhadap $S G R=0,743$. 
Arief Rahman, Warto Utomo, Bangbang Panca Kusuma, Muhammad Thariq Almuqtadir

\section{Bibliografi}

Aryani, Yanti, \& Gustian, Dudih. (2019). Sistem Informasi Penjualan Barang dengan Metode Regresi Linear Berganda Dalam Prediksi Pendapatan Perusahaan. https://doi.org/10.2005/jursistekni.v2i2.47. Google Scholar

Data, Patra Nusa. (2006). Indonesia Basin Summaries (IBS). Google Scholar

Dolan, Paul J. (1988). The geology of the Wiriagar field, Bintuni basin, Irian Jaya. Google Scholar

Ghifary Ardiansyah, Ahmad, Sapto Mulyanto, Bagus, Haerudin, Nandi, \& Purba, Humbang. (2018). Karakterisasi Sesar Sealing Dan Non Sealing Dengan Metode Seismik Inversi Impedansi Akustik dan Shale Gouge Ratio Pada Lapangan Teapot Dome Usa. Jurnal Geofisika Eksplorasi. Google Scholar

Handyarso, Accep, \& Mauluda, A. D. (2018). Penerapan Metode Dekonvolusi Euler untuk Estimasi Kedalaman Sumber Anomali. GEOMATIKA, 24(1), 21-30. Google $\underline{\text { Scholar }}$

Handyarso, Accep, \& Padmawidjaja, Tatang. (2017). Struktur Geologi Bawah Permukaan Cekungan Bintuni Berdasarkan Data Gaya Berat. Jurnal Geologi Dan Sumberdaya Mineral, 18(2), 53-65. http://dx.doi.org/10.33332/jgsm.geologi.v18i2.125. Google Scholar

Hartanto, Sri, Sapiie, Benyamin, Gunawan, Indra, \& Wibowo, Bintoro. (2018). Analisis Sekatan dan Karakteristik Sesar pada Formasi Kujung Reef di Kompleks Lapangan Ke, Cekungan Jawa Timur: Implikasi Terhadap Migrasi Hidrokarbon. Bulletin of Geology, 2(1), 134-148. https://doi.org/10.5614/bull.geol.2018.2.1.1. Google $\underline{\text { Scholar }}$

Maulananingsih, Nur Wahyu, Hartantyo, Eddy, \& Anggraini, Ade. (2015). Simulasi Sebaran Porositas dan Permeabilitas Reservoir Jurassic Menggunakan Analisis Geostatistika di Lapangan "Iriyanti" Cekungan Bintuni. Jurnal Fisika Indonesia, 19(57). Google Scholar

Rasimeng, Syamsurijal, Ririn, Yulianti, Karyanto, Karyanto, Hidayat, Hidayat, \& Muhammad Indragiri, Noor. (2018). Identifikasi Struktur Bawah Permukaan Menggunakan Metode Magnetotellurik 2D di Daerah Cekungan Bintuni Sebagai Potensi Hidrokarbon. Jurnal Geofisika Eksplorasi, 4(2), 109-114. Google Scholar

Sapiie, Benyamin ${ }^{1}$, Naryanto, W., Adyagharini, Aileron C., \& Pamumpuni, Astyka. (2012). Geology and tectonic evolution of bird head region Papua, Indonesia: Implication for hydrocarbon exploration in Eastern Indonesia. Search \& Discovery Article, 30260. Google Scholar

Yielding, Graham, Freeman, Brett, \& Needham, D. Tim. (1997). Quantitative fault seal prediction. AAPG Bulletin, 81(6), 897-917. https://doi.org/10.1306/522B498D1727-11D7-8645000102C1865D. Google Scholar 